\title{
SUBMICROSCOPIC STRUCTURE OF BOVINE ARTICULAR CARTILAGE IN PRENATAL AND EARLY POSTNATAL PERIOD
}

\section{HORKY}

Department of Anatomy, Histology and Embryology, University of Veterinary Science, 61242 Brno

Received January 10, 1986

\begin{abstract}
H o r k ý D.: Submicroscopic Structure of Bovine Articular Cartilage in Prenatal and Early Postnatal Period. Acta vet.Brno, 56, 1987:3-18.

The bovine joint cartilage was studied in 14 subjects of both sexes from the 36th week of prenatal development till the end of the third month after birth using transmission and scanning electron microscopes. Between weeks 36 and 39 , pericellular and intercellular matrix differentiated in the intercellular substance of the superficial layer of the cartilage. In the middle layer the fibrillar component was mostly represented by collagen fibrils. In the deep layer of the cartilage, these fibrils surrounded the cells and coursed irregularly in the intercellular matrix. From birth till the end of the third month of the cellular component and the intercellular substance of the joint cartilage acquired all substantial features of a differentiated tissue. Especially the fibrilar component of the superficial cartilage layer showed a typical arrangement in layers of collagen fibrils deposited in parallel with the surface of the cartilage. The filaments crossed at nearly right angles. After the third month only quantitative changes occurred consisting in the increased amount of fibrilar component as compared to the adult cartilage. In scanning electron microscope the groups of chondrocytes were separated from each other and from their surroundings by indentations.

Submicroscopic structure, cattle, cartilage layers, hip joint.
\end{abstract}

From the developmental, microscopic and functional point of view the joint represents a specially differentiated cavity originating in the blastema ground skeleton of mesenchyma, which is perfectly adapted to its function in the organism locomotion. The joint is formed partly by articular cartilage which covers bone ends, partly by cartilage cavity cushioned by synovial membrane connected to the outer layer of cartilage capsule. Its integral part then is the synovial fluid which fills the articular cavity. Synovial fluid is produced by synovial membrane playing thus important role in cartilage by securing the nutrition of joint cartilage cells and by 
decreasing friction of loaded cartilage areas.

It is generally known that joint cartilage originates from mesenchyma in the course of skeleton development as a component of cartilage blastema of bone ground which is rebuild to the final bone in the course of ossification. While the whole preformed bone ground is being gradually destructed, this process does not affect the joint cartilage retaining it in the direction to the joint cavity (B o n u c c i 1967; S c h e r f t 1972; T h y b e r g 1973; A n d e r s o $n$ and $S$ a $j d e r$ a 1976; A 11 1976; F e $1 i x$ and F 1 e $i \mathrm{~s} h$ 1976; $H$ a $n$ a $\circ$ a 1976). Condensation process of mesenchyma in blastema takes place in the early period of embryogenesis, so that according to $G$ a $r$ d $n$ e and $0^{\prime} R$ a $h i_{1} 1 \mathrm{y}$ (1968) already in stage 18 according to $S t r$ e e $t$ e $r$ (that is about 6 th week after ovulation) chondrification of the femur begins, and in the 8th

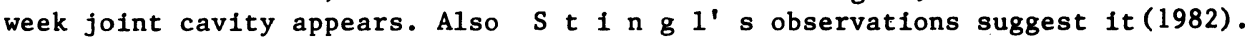
During this process vessels of perichondrium grow into the cartilage ground (H a I n e s 1933; H u r r e 1 1934; L e ve ne 1964; L u f t 1 1970; S t o c k w e 111971 a; A g r a v a 1 et al. 1984) not intruding the area of the future joint cartilage ( $\mathrm{r}$ a $\mathrm{y}$ and $\mathrm{G}$ a r d n e r 1969; $G$ a $r \mathrm{~d}$ $\mathrm{n} e \mathrm{r}$ and $\mathrm{G} \mathrm{r}$ a $\mathrm{y}$ 1970) and dissappear about the 10th week. Before the joint cavity is formed a larger amount of small cavities appears in mesenchyme in the contact area of the future joint bone spaces. Its final formation helps also the earlier formed muscles and ligaments in the area of joint ( $\mathrm{r} a \mathrm{chm} \mathrm{m}$ and $\mathrm{S} \circ \mathrm{k} \circ \mathrm{l} \circ \mathrm{f} \mathrm{f}$ 1966) and may be, even the first movements (G 1 e $n i s$ e $r$ 1976). Owing to the process of ossification obtain chondrocytes their characteristic place, according to $\mathrm{G} \circ \mathrm{d} \mathrm{m}$ a $\mathrm{n}$ et al. (1960), Go u $1 \mathrm{~d}$ et al. (1974) and $\mathrm{L} \mathrm{e} \in \mathrm{t} t$ and D o r f $\mathrm{m}$ a $\mathrm{n}$ (1974). It should be stated of course that all mentioned articles deal with the development of joint cartilage only partly, referring to generally known informations. A much greater attention is given to the study of chondrogenesis by rabbits ( $P$ u $1 \mathrm{~g}-\mathrm{R}$ o $s$ a $\mathrm{d} \circ$ 1981) or birds and to its influence when using tissue cultures $\mathrm{G}$ e e $\mathrm{n}$ (1971), $\mathrm{S} \mathrm{ch} \mathrm{e} \mathrm{ck}$ et al. (1975), L a m a r et al. (1980), B e $k$ of $f$ and $K 1$ a g s b r u n (1983), $S$ a $t o$ and $U$ r 1 s $t$ (1984) as well as stating explicit characteristics considering differentiation of chondrocytes with non differentiated cells (citation $S \circ 1 \mathrm{u} \mathrm{s} \mathrm{c}$ et al. 1982; B u ckwa $1 \mathrm{ter}$ and $R \circ s$ e $n$ b e $r g$; 1983). Some articles are dealing only with partial problems as regulation mechanisms in relation to bone-cartilage ( $1 \mathrm{j}$ we $1 \mathrm{~d}$ e 1982) or with incidence of cilla ( $11 \mathrm{~s} \mathrm{~m}$ a $\mathrm{n}$ and $F 1 \mathrm{e} \mathrm{t-}$ $\mathrm{c} h$ e r 1978; V $1 \mathrm{~d} \mathrm{i}$ o $\mathrm{v}$ and $\mathrm{V}$ a s $11 \mathrm{e} v$ 1985) eventually other types of cartilage ( $\mathrm{i} 1 \mathrm{~b}$ e $\mathrm{rm}$ a $\mathrm{n}$ and $\mathrm{Fr} \circ \mathrm{m} \mathrm{m}$ r 1974; $\mathrm{S}$ a $\mathrm{n}-$ $z \circ n e$ and $R$ e $i t h$ 1976). We are left in this branch to results of our own study.

\section{Material and Methods}

Samples of bovine joint cartilage were collected from 14 individuals of both sexes, 8 to 40 weeks after fertilization for ultrastructure study in a transmission and scanning electron microscope. Material was taken mostly in a slaughterhouse.

Samples from femur head in direction to large trochanter were collected, in the early development stage then the whole head. Stripes of $1 \times 1 \times 3-$ $5 \mathrm{~mm}$ were cut and divided into blocks of $1 \times 1 \times 2-3 \mathrm{~mm}$, then processed in a standard way.

Samples for scanning electron microscopy were collected from joint cartilage quite close to place where sections for scanning electron 
microscopy were cut out. Their size reached at least $5 \times 5 \mathrm{~mm}$.

U1trathin sections were cut on Ultracut Reichert microtome, then stained with lead citrate or uranyl acetate followed by lead citrate. These sections were viewed and photographed by Tesla BS 500 electron microscope. From the embedded material also semithin sections for light microscopy were cut and stained with $1 \%$ methylene blue and Azure II.

Samples of already mentioned sizes were also taken for the study of joint cartilage surface in a scanning electron microscope and before fixation left 15 minutes either in $1 \%$ hyaluronidase solution of $0,1 \mathrm{mg} / \mathrm{ml}$ concentration at $20^{\circ} \mathrm{C}$ or washed $3 \times 15$ minutes in saline. This space of time is sufficlent to remove rests of synovial fluid from the surface of joint cartilage without dammaging it. When using hyaluronidase samples were being washed $3 \times 15 \mathrm{~min}$. in saline, then fixed in $10 \%$ formol or glutaraldehyde for 10 to 14 days. After fixation the tissue was dehydrated by method of critical point and coated with gold on a Blazer's coating apparatus. The surface was studied by a Stereoscan Cambridge Scanning Microscope.

$$
\begin{aligned}
& \text { U l t r a t r u t u r of joint cartilage } \\
& \text { i n the period of } 36 \mathrm{th} \text { to } 39 \mathrm{th} \text { we e } \\
& \text { a f t e } r \text { fertilizat ion }
\end{aligned}
$$

The joint cartilage in this period undergoes further differential changes, so. that towards the end of pregnancy it resembles in a considerable measure by its characteristics an adult cartilage. Whereas cells of the superficial layer keep the appearance similar to the preceding stage of development ( $H \circ \mathbf{r} k \dot{y}$ 1985), cells of the middle and deep layer have all characteristics of differentiated chondrocytes. Significant changes in the intercellular substance, first of all in the middle and deep layer, occurred.

$S u b m i c r o s c o p i c s t r u c t u r e$ of chondroblast $\mathrm{s}$ of the superficial la yer

Chondroblasts of the superficial layer are spindle-shaped elongated cells, placed in the intercellular substance in $1-2$ layers above one another reaching size of $10-12 \mu \mathrm{m} \times 3-5 \mu \mathrm{m}$.

$\mathrm{N}$ u c 1 e u s

Nucleus is of rod-like elongated shape, its appearance does not differ from nuclei of chondroblasts of the superficial layer of joint cartilage in the earlier developmental stage (Fig. 1).

C y toplas $\mathrm{m}$

There is a rather small amount of cytoplasm; it is mostly gathered on both cell ends and in shape of a narrow rim surrounds nucleus (Fig. 1).

G r a n l a r e n d o pla s m i c r e t i c u l u m occurs in the cytoplasm as few mostly short cisternae or vesicles, situated near the nucleus and partly in areas of larger accumulation of cytoplasm. Its spaces are filled by a synthesized material of granular or filamentous appearance of medium electron density (Fig. 1). 
A g r a n u la r e n d o plas mic reticulum is present as single smooth vacuoles partly near the cell membrane, partly also among cisternae of granular endoplasmic reticulum (Fig. 1).

$\mathrm{G}$ o $\mathrm{lg}$ i c o $\mathrm{m} \mathrm{ple} \mathrm{x}$ occupies only a small part of the cytoplasm and its structures are very little distinct.

There is a small number of $\mathrm{m} i \mathrm{t} o \mathrm{c}$ o $\mathrm{n} \mathrm{d} \mathrm{r}$ a reaching about 0,3 to $0,5 \mu \mathrm{m}$ in size.

We did not prove any 1 y $s$ o $o \mathrm{~m} e \mathrm{~s}$ in the cytoplasm of chondroblasts of the superficial layer.

$\mathrm{C}$ e $1 \mathrm{ll} \mathrm{m}$ e $\mathrm{m} \mathrm{b} \mathrm{r}$ a $\mathrm{n}$ e covers variously formed projections of cytoplasm; they are few in number and project at irregular distances. Some of them are branching and therefore it is possible to find their transverse sections near the cell. Projections reach about 0,5 to $0,8 \mu \mathrm{m}$ in size and do not enter the intercellular matrix. Cell membrane forms solitary pinocytotic vesicles.

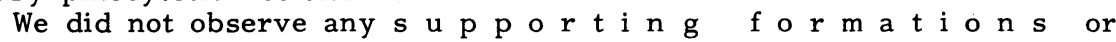
c i 1 i a.

$\mathrm{G} \mathrm{l}$ y $\mathrm{c}$ o $\mathrm{g}$ e $\mathrm{n}$ was present in the form of typically few granules dispersed in the cytoplasm or forming small clusters (Fig. 1).

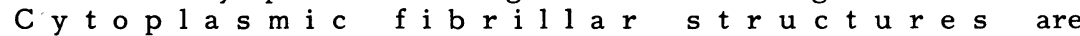
less conspicuous having shape of diffusely dispersed filaments near nucleus.

$S u b m i c r o s c o p i c s t r u c t u r e$ of c hondroblasts of the middle layer.

Chondrbblasts of the middle layer (Fig. 2) are oval to. irregularly triangular cells, mostly separately deposited in the intercellular substance, in pairs only sporadically. They reach size of $8-9 \times 5 \mu \mathrm{m}$ and already in this stage of development they have an appearance of adult chondrocytes.

$\mathrm{Nucle}$ us

Most cells have an oval nucleus reaching about $5 \times 3 \mu \mathrm{m}$ in size (Fig. 2,3).

$\mathrm{N}$. u c l e a r e $\mathrm{n} v$ e $1 \circ \mathrm{pe}$ is formed by two membranes which surround in between a narrow perinuclear area and on some places form nuclear pores. To the outer membrane ribosomes are attached. We observed the connection of the outer membrane with cisternae of granular endoplasmic reticulum only exceptionally.

$\mathrm{C} \mathrm{h} \mathrm{r} \mathrm{o} \mathrm{m} \mathrm{a} \mathrm{t}$ i forms karyosomes mostly deposited at the inner membrane of nuclear envelope. Some karyosomes are situated irregularly on the section of nucleus (Fig. 2,3). Zonula nucleum limitans about $0,5-0,8$ $\mu \mathrm{m}$ thick is situated between chromatin and nuclear envelope.

$\mathrm{N}$ u c l e o l u s is often found as well as nucleoli with nucleolonema which we always observed (Fig. 2).

C y to p l a s m

As to the amount and equipment of organelles the cytoplasm does not differ from the cytoplasm of chondroblasts of the middle layer of previous stage of development.

When compared with the previous layer $g r$ a $n$ u 1 a $r$ 
e $\mathrm{ndoplasmic} r$ e $\mathrm{t}$ i c u l u m is present in a larger amount. It is arranged either as vesicles or rather numerous flattened cisternae, often deposited in several layers above one another. The ends of cisternae widen rod-shaped and through suppressing vesicles arise from them coated also by ribosomes (Fig. 2,3). Inside of all the structures synthesized material of usual appearance occurs.

A g r a n l a r e n d o plas m i c re t i c u l u m is represented by only quite sporadic smooth vesicles.

$\mathrm{G} \circ \mathrm{lg} \mathrm{i} \quad \mathrm{c} \circ \mathrm{mpl} \mathrm{e} \mathrm{x}$ is a distinct structure of the cytoplasm of chondroblasts of the middle layer (Fig. 2,3). It occupies a rather large part of the cytoplasm and in some cases is composed of a larger number of single Golgi fields. Vesicles of different size separate from dictyosomes, some of them gradually changing to transport vacuoles containing rather dense fibrillar or granular substance (Fig. 2,3).

$\mathrm{M}$ i t $\circ \mathrm{c} \mathrm{h}$ o $\mathrm{nd} \mathrm{r}$ i a are few in number. Being usually of oval shape they reach about $0,5-0,6 \mu \mathrm{m}$ in size (Fig. 2).

$\mathrm{L} y \mathrm{~s}$ o $\mathrm{s} \mathrm{m}$ e $\mathrm{s}$ are rare in the cytoplasm of chondroblasts of this layer. Provided we found them they were mostly multivesicular corpuscles (Fig. 3). layer.

We did not prove any c e n t r i o l e s or c ili a in this

C e 11 m e m b $r$ a $n$ e. The cytoplasm on the whole surface makes short wide projections covered by cell membrane. Their length does not reach more than $0,8 \mu \mathrm{m}$ and they are usually ending at the intercellular matrix (Fig. 9). Pinocytotic vesicles are only sporadic.

$\mathrm{G} l \mathrm{y}$ c o $\mathrm{g}$ e $\mathrm{n}$ occurs in the same amount and arrangement as in the previous layer (Fig. 2,3).

C y toplasmic fibrillar formations occur in a small amount as thin bundles of filaments either near nucleus and Golgi complex or near the cell membrane (Fig. 2,3).

$S u b$ m i $r$ os c o p i c s t r u c t u r e of

chondroblasts of the deeplayer

Chondroblasts of the deep layer are cells of round half-moon-like or elongated, sometimes triangular shape reaching size of about $8 \times 4-5 \mu \mathrm{m}$. They are deposited in the intercellular substance of the deep layer of joint cartilage either in groups or in short columns (Fig. 4).

$\mathrm{N}$ u c l e u s

In comparison with chondroblasts of the middle layer is nucleus smaller. Its appearance and structure does not differ from nuclei of cells of the previous layer.

C y top las m

In relation to nucleus is the cytoplasm large and as to organelles, does not differ from chondroblasts of the deep layer of the previous stage.

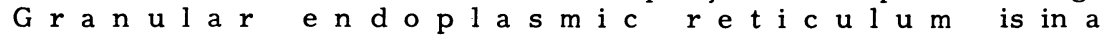
great majority formed of dilated capsules, only a smaller part has appearance of narrow flattened cisternae. Between both forms numerous interconnections are formed so that individual layers are connected with one another (Fig. 4). Widened cisternae and vacuoles separate cytoplasm 
into small areas, and membranes of reticulum lean then close on other organelles, for example mitochondria (Fig. 4).

A g a n u l a e ndoplas micereticulum is arranged in the same way as in the previous layer.

$\mathrm{G} \circ \mathrm{lg} \mathrm{g} \circ \mathrm{m} \mathrm{ple} \mathrm{x}$ is in contrast to the cells of the middle layer little distinct. It is usually formed by one dictyosome and mostly by small capsules (Fig. 4).

$M$ i $t \circ c h \circ n d r$ i a have the same structure as in the middle layer, only quite often we encounter their elongated forms (Fig. 4).

$\mathrm{L} y \mathrm{~s}$ o $\mathrm{s}$ o $\mathrm{m}$ e $\mathrm{s}$ occur in the cytoplasm of chondroblasts of this layer rather often. They appear as dark corpuscles reaching size of 0,3 $0,5 \mu \mathrm{m}$ (Fig. 4).

$\mathrm{C}$ e $\mathrm{n} \mathrm{r}$ i o l e s and c i l i a were not observed.

C e $1 \mathrm{l}$ m e $\mathrm{m}$ b $r$ a $\mathrm{n}$ e. Cytoplasm on the whole periphery of cells forms numerous short projections covered by cell membrane. Only exceptionally projections of $0,5-0,6 \mu \mathrm{m}$ occur, found mostly in areas where the intercellular matrix approaches the cell membrane (Fig. 4). Should the cells be of elongated or irregularly star-like shape, the cell membrane is arranged in the same way as by chondroblasts of the deep layer of the previous stage.

$\mathrm{G} \mathrm{l}$ y $\mathrm{c} \circ \mathrm{g} \mathrm{e} \mathrm{n}$ is a regular component in the cytoplasm of cells of the deep layer (Fig. 4). Small clusters of its granules are irregularly dispersed in the cytoplasm among other organelles.

C y toplas mic fibrillar st $r$ u c t u r e are a very discrete part of the cytoplasm of chondroblasts of this layer. When observed, they did not differ by their arrangement and deposition from cells of the middle layer.

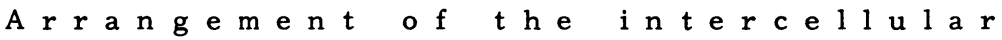
s u b s a n c of the joint cartilage

In the period of 36 th to 39 th week after fertilization, the largest changes occurred in the composition of the intercellular substance in the middle and deep layer, whereas the superficial layer changed only slightly.

In contrast to the previous developmental period, in the upper layer specialized spaces (pericellular matrix) around the cells arise. It is mostly formed by ground amorphous substance and aperiodic fibrils. Thus formed space is well developed especially in areas which incline to the surface of cartilage, whereas in the direction to deeper layers near cell membrane typical collagen fibrils penetrate (Fig. 1). The proper peripheral layer is build in the same way as in the previous stage.

In the middle layer there comes to a considerable increase of fibrillar component (Fig. 2,3) represented both by typical collagen fibrils and a small amount of aperiodic fibrils. The pericellular matrix is already distinctly formed around greater part of the cellular surface, and, as a rule, collagen fibrils get in contact with the cell membrane only on one pole of the cell. Collagen fibrils in the intercellular matrix are irregularly arranged and we can find them on elongated as well as transverse sections.

The area of pericellular matrix is most distinctly differentiated in the deep layer (Fig. 4) where the attached areas between column-like deposited chondroblasts are filled by this matrix, whereas on the averted areas this district is narrow or even missing, so that the intercellular matrix analogically to the middle layer adjoins with the cell membrane of chondroblasts of the deep layer. In the intercellular matrix, the fibrillar component forms an irregular and dense mesh-work. 
A p p e a r a c e of jo int c a r t i l a ge i n s c a n i n g e l e ct ro $n$ mi c r o s c o p e

Appearance of the bovine joint cartilage in the 8th to 10th week of prenatal development is similar to human cartilage in the same period ( $H \circ r k y$ 1984). We quoted first changes during the 20th to 23th week, when its surface appearance begins to form slightly differently ( $H \circ \mathbf{r} k \dot{y}$ 1985).

The surface of the joint cartilage is rather uneven in this period. Several elevations of elongated spindle-like shape are prominent above its surface. In some cases the pairs of elevations are surrounded by furrows. Formations resembling the cipher 8 or rarely even in groups of 4 occur, separated from their surroundings by a common furrow.

The process of "immersing" and separating of individual elevations or of their pairs from the surrounding area continues and is important during the 36 th to 39 th week of development (Fig. 5). One can see that numerous elevations with a distinct spindle-like shape in the previous stage are becoming round and their amount decreases. At the same time they draw nearer to each other forming areas of accumulation of elevations. Among such districts areas without prominences with a fine wrinkled surface may be found. Surrounding furrows are deep and elevations are placed in thus formed grooves (Fig. 6).

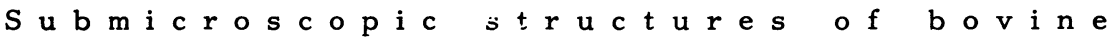
jo int c a r t i l a g i n e a r l y p o s $t$ n a $t$ a 1 p e r i o d

In the second part, we deal with the description differentiation changes in the period, when the joint cartilage of postnatal period resembles in main features the cartilage of adult individuals. Comparison of our results reveals that in cattle it occurs at about 3 months of age. The joint cartilage in this period the appearance of differentiated tissue which can be, according to the appearance of cells and the intercellular substance, divided into three layers. Cells of all the layers have already signs of typical chondrocytes; also the arrangement of intercellular substance resembles that of the adult cartilage.

$S u b m$ i c r o s c o p i c s t r. u c t u r e o f $c h o n d r o c y t e s$ o f $t h e$ s p e r f c i a l l a e r

Chondrocytes of the superficial layer are spindle-shaped elongated cells, usually deposited in two rows above one another and oriented in parallel with the surface of cartilage. They reach size up to $12 \times 2-3 \mu \mathrm{m}$.

$\mathrm{N}$ u c 1 e u s

The nucleus is of a very elongated rod-like shape, only sporadically oval (Fig. 7).

$\mathrm{Nucl}$ e a $\mathrm{r}$ e $\mathrm{n}$ e lo $\mathrm{pe}$ is formed by two memtranes which make little numerous nuclear pores. The perinuclear space is narrow, the interstage of membrane envelope to structure of granular endoplasmic reticulum was not observed. Nuclear envelope is smooth, only on poles of nuclear is projecting against karyoplasm into wide shallow invaginations (Fig. 7). 
$\mathrm{C} \mathrm{h} \mathrm{r}$ o $\mathrm{mat} \mathrm{i} \mathrm{n}$ is partly condensed into karyosomes deposited at the inner membrane of nuclear envelope, partly is forming one large cluster partitioning nucleus (Fig 7). Zonula nucleum limitans is distinctly formed in a shape of strip of middle osmiophilic fine granulated substance between chromatin and inner membrane of nuclear envelope, reaching size of $0,1 \mu \mathrm{m}$.

$\mathrm{N}$ u c l e o l u s. We observed nucleolus rarely on sections of nucleus of chondrocytes of the superficial layer.

\section{C y top 1 a s m}

There is a larger amount of cytoplasm in comparison with chondroblasts of the superficial layer of previous stage, containing also more organelles.

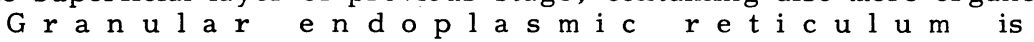
formed by numerous mostly flattened cisternae, in some cases deposited above one another (Fig. 7,8). In some chondrocytes dilated structures of reticulum, resembling vacuoles prevail. Flattened cisternae as well as vacuoles are filled with synthesized material of common appearance.

A g r a n a r e n d o plas m i c r e t i c u l u m occurs only sporadically. Some of the large vacuoles, enveloped by a smooth membrane are formed by folds of the nuclear membrane.

$\mathrm{G} \circ \mathrm{lg} \mathrm{i} \quad \mathrm{c}$ o $\mathrm{m} \mathrm{p} 1 \mathrm{e} x$ is strongly developed and laid out in to several fields. From its dictyosomes a number of mostly small Golgi vacuoles (Fig 7,8 ) separate, as well as single vacuoles of about $0,5 \mu \mathrm{m}$ with dense granulated substance, which represent transport vacuoles.

$\mathrm{M}$ i $\mathrm{t} \circ \mathrm{c} \mathrm{h} \circ \mathrm{n} \mathrm{d} \mathrm{r}$ a reach the size of $0,5-1 \mu \mathrm{m}$, in comparison with the previous stage we often observed their elongated forms (Fig. 8). Their matrix was often cleared.

$\mathrm{L}$ y $\mathrm{s} \circ \mathrm{s} \circ \mathrm{m}$ e $\mathrm{s}$ as well as centrioles and cilia were not observed in chondrocytes of this layer.

$\mathrm{C}$ e $1 \mathrm{l} \mathrm{m} \mathrm{e} \mathrm{m} \mathrm{b} \mathrm{r}$ a $\mathrm{n}$ e. The cytoplasm is not arranged in the same manner on the whole surface. On the area leaning to the surface of cartilage it is more or less smooth or only slightly waved (Fig. 7,8 ). Towards the middle layer it makes rather numerous often winding up and differently long projections reaching the intercellular substance, where their transverse or oblique cuts can be seen (Fig. 8). Collagen fibrils are surrounded by projections that nearly close them (Fig. 8).

$\mathrm{G} l \mathrm{y} \mathrm{c}$ o $\mathrm{g} \mathrm{e}$ is regularly present in the cytoplasm of chondrocytes of this layer in form of sporadic small clusters of granules, deposited irregularly among organelles (Fig. 7,8).

C y toplasmic fibrillar st r u t u r e s are forming strong bundles and occupy a great part of the cytoplasm on the periphery of the cell. We observed them near nucleus as fine bundles of fibrils (Fig. 7,8 ).

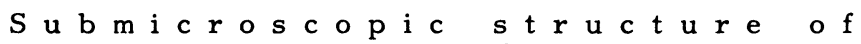
chondrocytes of the midd le la ye $r$

Chondrocytes of the middle layer are oval to triangularly rounded cells reaching a size of $8-9 \times 6 \mu \mathrm{m}$. They are deposited in the intercellular substance single or in pairs. 
$\mathrm{N}$ u c 1 e u s

In most cases is the nucleus rounded or slightly oval on section. Its size, appearance and structure does not differ from nuclei of chondrocytes of the middle layer of previous stage or of those of an adult cartilage (Fig. 9).

C y top 1 a s m

Chondrocytes contain a larger amount of cytoplasm as against fetal cells. The cytoplasm is accumulated at one pole and the nucleus at the opposite pole of the cell (Fig. 9).

G $r$ a n l a r e n d o plas m i $\quad r$ e $t$ i c u l u m is formed by numerous wide dilated cisternae interconnected with one another and by vesicles which separate themselves from bulb-shaped widened cisternae (Fig. 9). All the inner spaces of reticulum are filled by synthesized material.

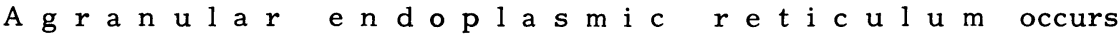
only sporadically as single vacuoles, mostly deposited near the cell membrane.

$\mathrm{G} \circ \mathrm{lg} \mathrm{g} \quad \mathrm{comple} \mathrm{m}$ is well developed and in the cytoplasm of chondrocytes of this layer occupies a large portion of the cytoplasm (Fig. 9). From its cisternae a large amount of vacuoles of different sizes including transport vacuoles reaching up to $1 \mu \mathrm{m}$ (Fig. 9) arise through spliting.

Two sizes of $\mathrm{m}$ i t o $\mathrm{c} \mathrm{h}$ o $\mathrm{n} \mathrm{d} \mathrm{r}$ i a were observed: a smaller one (about $0,5-0,6 \mu \mathrm{m}$ ) with usual arrangement of cristae and appearance of matrix, and a larger one $(1,5-1,8 \mu \mathrm{m})$ with damaged cristae and clear matrix (Fig. 9). It seems that in the second case the mitochondria were disintegrating.

$\mathrm{L} y \mathrm{~s}$ o $\mathrm{s}$ o $\mathrm{m}$ e s occur in the cytoplasm of chondrocytes of this layer only sporadically as well as centrioles.

$\mathrm{C}$ e $1 \mathrm{l} \mathrm{m}$ e $\mathrm{m} \mathrm{b} \mathrm{r}$ a $\mathrm{n}$ e. The cytoplasm on the whole surface forms projection covered by cell membrane. Their length does not exceed more than $1 \mu \mathrm{m}$, width $0,4 \mu \mathrm{m}$. Cytoplasmic projection bridge a somewhat narrow space of pericellular matrix ending on at the border of pericellular and intercellular matrix (Fig. 9). In some areas collagen fibrils attach closely to the cell membrane.

G $1 \mathrm{y} \mathrm{c} \circ \mathrm{g}$ e $\mathrm{n}$ occurs in the cytoplasm of chondrocytes of the middle layer in a larger amount than in cells of the superficial layer (Fig. 9).. Its granules form small clusters irregularly dispersed in the cytoplasm and near the pole of the cell usually one larger area also, where a part of glycogen can be washed out (Fig. 9).

C y top las mic f i b r i l l a r s t r u c t $r$ e $s$ form bundles of filaments, which can be observed on the elongated as well as transverse section often near the cell membrane (Fig. 9).

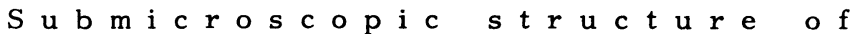
c hondrocyte $\mathrm{s}$ of $\mathrm{the} d \mathrm{e}$ e $\mathrm{p}$ l a y e

Chondrocytes of the deep layer are mostly cells of irregular prismatic shape size $6 \times 6 \mu \mathrm{m}$, placed in the intercellular substance usually in pairs in one capsule (Fig. 10). 
N u c l e u s

The nucleus is of irregular shape (about $5 \times 3 \mu \mathrm{m}$ ).

$\mathrm{N} \mathrm{u}$ c l e a $\mathrm{r}$ e $\mathrm{n} \mathbf{v}$ e lo $\mathrm{p} e$ is of standard structure, partly nearly smooth, at places forming wide shallow indentations (Fig. 10).

$\mathrm{N} u$ c l e o l u s is small, of reticular type, surrounded by perinuclear chromatin (Fig. 10).

C y $\mathrm{t} \circ \mathrm{p} \mathbf{l}$ a $\mathrm{s} \mathrm{m}$

The cytoplasm is arranged in the same manner and contains organelles in the same amount as the cytoplasm of chondroblasts of the deep layer of joint cartilage in the previous developmental period. The difference at this stage (Fig. 10) is the striking occurrence of intracytoplasmic filaments, at this stage of development which occupy rather large areas of the cytoplasm and in form of thick bundles surround the nucleus.

\section{A r r a n g ment of intercellular substance}

The intercellular substance of joint cartilage of 3 months old individual differs from the adult cartilage first of all by its thickness and arrangement of fibrillar components of the superficial layer. The peripheral layer proper is covered by a nearly continuous chondral membrane of the same appearance as is the human cartilage. Under the chondral membrane (Fig. 8 ) is an almost $1 \mu \mathrm{m}$ thick layer of intercellular substance, where the fibrillar component is represented by a mesh-work of mainly collagen fibrils and already at this stage one can follow the deposition of fibrils crossing each other at right angles as a basis of future layer arrangement of the fibrillar component of the superficial layer in an adult cartilage. The pericellular matrix is distinctly formed predominantly on the side which turns to the joint cavity whereas this area on the opposite side of chondrocytes is not formed and the collagen fibrils are in close contact with the cell membrane (Fig. 8).

In the middle layer is the pericellular matrix formed on the whole periphery of chondrocytes (Fig. 9). Only exceptionally collagen fibrils besides aperiodic fibrils reach into this area. In the surrounding intercellular matrix collagen fibrils form a distinctly thicker layer (about $1-1,5 \mu \mathrm{m}$ wide) which surrounds the chondrocyte. Behind this area, the collagen fibrils are mesh-work-arranged (Fig. 9).

In the deep layer pairs of chondrocytes are placed in one common capsule (Fig. 10) and between the cells no septum is formed. Pericellular matrix is very distinct and is composed of aperiodic fibrils and amorphous substance. It reaches a size of $1-1,5 \mu \mathrm{m}$; its part are also sections through the cytoplasmic projections of chondrocytes. Collagen fibrils of the intercellular matrix surround lacunae of chondrocytes. In this layer, $2 \mu \mathrm{m}$ thick, collagen fibrils are arranged in parallel with its surface (Fig. 10). Behind this layer bundles of collagen fibrils arranged irregularly in the amorphous layer can be seen. 


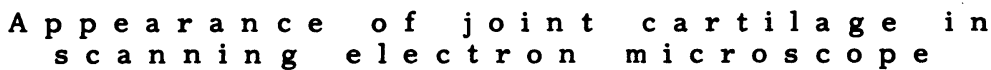

The surface of joint cartilage 3rd month after birth differs only little from the adult cartilage and is formed in two manners. From place to place (Fig. 11,12) wide shallow grooves are formed, on their bottom elevations equal to those of the previous stage are situated. These round to slightly elongated formations are surrounded by a rather deep incision and a mound from the near-by prominences (Fig. 12). Between thus formed districts large areas occur, the surface of which is wrinkled by fine and coarse crest-like lines coursing in parallel (Fig. 11,12). The fine crests may reach also into the area of elevations surrounding humps as well as onto their surface.

\section{Discussion}

When studying the ultrastructure of bovine joint cartilage we stated already before ( $H \circ \mathbf{r} \quad k \dot{y}$ 1983) that in the world literature no sufficient attention had been to this problem. There is a similar situation as to the development of joint cartilage of this animal species, for only a few articles were published dealing with the morphology of joint cartilage during development. But in no case was described its development on submicroscopic level in a more or less continuous periods since the stage when joint cavity is being formed (that is about the 8th week after ovulation) till the time after birth, when its structure, except for certain quantitative signs, agrees on the whole with the structure of an adult cartilage. From this point of view our findings are original. Articles dealing with this problem

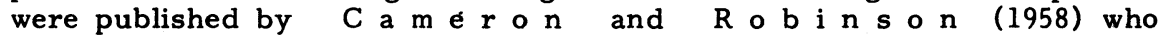
but only compared matrix formation of epiphyseal and articular cartilage. B r o w e r and $H$ s u (1969) and $S t \circ c k$ w e 11 (1971) observed vessel supply of joint cartilage and diffusion possibility of substances from the cartilage canals in to the intercellular substance in different mammalian species, or thickness of joint cartilage and density of chondrocytes ( $\mathrm{Sto} \mathrm{ck}$ w e $11 \quad 1971$ a). We are therefore going to confront results of our own study with the findings on joint cartilage in other animals including man as far as they should have common validity.

A conspicuous sign of chondroblasts of the superficial layer during its period of development is the manner of their deposition. It is generally reported that this orientation is conditioned by pressure forces which affect

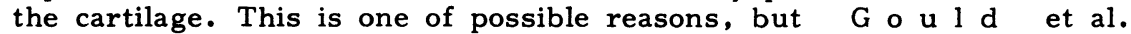
(1974) pronounced an interesting statement, according to which this orientation is a product of the formation of intercellular substancei. Chondroblasts are thus compressed by this substance produced in the area of chondrification centre. While during the prenatal development the pressure forces are restricted only to pressure development by muscles, one cannot omit this point of view even if no cause is found why the stated pressure of the intercellular substance does not make itself on felt chondroblasts of the undersuperficial layers. It is probable that on the final arrangement of chondrocytes in the period of development both factors participate together and because of these forces also the course and arrangement of filaments of the intercellular substance changes, which together with the amorphous component are the bearers of mechanical properties of joint cartilage, whereas chondrocytes play the key role in their synthesis ( $\mathrm{B}$ a 1 a s z et al. 1966; I m u r a 1984; K l a m f e l d t 
1984). Chondrocytes of the superficial layer behold this arrangement also in adult age.

During the prenatal period chondroblasts of the superficial layer have appearance of little differentiated cells originating from mesenchyma for example fibroblasts. They keep this appearance practically until the $3 \mathrm{rd}$ month post partum, when their cytoplasm differs only very little froin chondrocytes of adult cartilage. They change their shape, but first of all organelles occur in the cytoplasm in an amount which is characteristic for differentiated cells and being of specific structure are these intracytoplasmic filaments of vimentin type ( $G \mathrm{~h}$ a d i a 1 l y 1983).

Zonula nucleum limitans is formed ( $\mathrm{H} \circ \mathrm{r} \mathrm{k} \dot{y} 1984 \mathrm{~b}$ ) in the nucleus during the whole period of development; its thickness, in agreement with literary data ( $\mathrm{r}$ y s c h a k et al. 1974) changes with increasing age.

In the middle layer differentiation of chondroblasts occurs already in a very early period, in our material from the 8 th week of development ( $\mathrm{H}$ o r$k$ y 1985). Chondroblasts of this layer differ during the whole period from cells of the superficial and deep layer by a greater amount of cytoplasm, a distinct granular endoplasmic reticulum, Golgi complex, a greater amount of elongated mitochondria and by a frequent occurrence of transport vacuoles. These signs are, according to $\mathrm{F} \mathrm{r}$ e e m a n (1973) typical for chondrocytes with an increased synthesis of components of the intercellular substance. Also data from $S \mathrm{t}$ o c k w e $1 \mathrm{l}$ and $\mathrm{M}$ e a c h i m (1979), who followed the level of synthesis of proteoglycans as well as mitosis, agree with the observation that this layer is, from the metabolic point of view, important also for growth of the cartilage. We also succeeded to observe mitosis in our material; its finding in a cartilage is generally infrequent ( G h a d i a l l y 1983). Similarly to S t o c k w e l l (1971 a), our material from the 8 th to 10 th week revealed in the intercellular substance of the middle layer blood capillaries and erythrocytes deposited partly among chondroblasts, partly phagocytized. In the later period capillaries did not occur in the joint cartilage, which agrees with observations of $G$ a $r$ $n$ e $r$ and $G \mathbf{r}$ a y (1970).

In the later period of development (16th to 23 th week after fertilization) appear in the superficial layer besides chondroblasts also temporary types of cells which we reported already before ( $H \circ r k$ ý 1983, 1985), which have already some characteristic typical of chondroblasts of the middle layer. It is first of all the conspicuous Golgi complex and often occuring centrioles. Chondroblasts of the middle layer do not differ by their appearance from the previous stage. The fact, that these are cells very active from the point of view of production of the intercellular substance is clear from our finding of penetration of collagen fibrils through the cell membrane into the intercellular space. We found this phenomenon only in a developing synovial membrane ( $\mathrm{H}^{\prime} \mathrm{r}$ $\mathrm{k}$ ý $1984 \mathrm{a}$ ); it was not described in chondrocytes.

Differentiation changes of chondroblasts as well as of the intercellular substance ar distinctly reflexing in the period of 36 th to 39 th week after fertilization. Whereas cells of the superficial layer behold appearance of less differentiation chondroblasts, they do not much differ in the middle and deep layer from adult chondröcytes ( $H$ o $\mathbf{r}$ k ý 1983).

The intercellular substance similarly to cells of joint cartilage undergoes a series of quantitative and qualitative changes during the prenatal period of development. It is formed in the early periods by an abundant amorphous substance with prevailing aperiodic fibrils. From the standtpoint of joint function the main role plays the superficial layer. During the period of 8 th to 10 th week of development the fibrillar component on the periphery of joint cartilage with the cavity of joint is composed only of aperiodic fibrils; about 
$1 \mu \mathrm{m}$ under the surface sporadic collagen fibrils appear. Chondrosynovial membrane is not formed ( $W \circ 1 \mathrm{f} 1969$, 1975) so that diffusion of substance from the joint cavity is easy ( $M$ a $r o u d$ a $s$ and $B$ u l$1 \circ \mathrm{u} \mathrm{g} \mathrm{h} \mathrm{1968;} \mathrm{M} \mathrm{a} \mathrm{r} \mathrm{o} \mathrm{u} \mathrm{d} \mathrm{a} \mathrm{s} \mathrm{1973)} \mathrm{and} \mathrm{thanks} \mathrm{to} \mathrm{the} \mathrm{small} \mathrm{amount}$ of collagen fibrils the pericellular and intercellular matrix is not formed. We found the first signs of formation of the chondral membrane on the surface of joint cartilage between 16th to 23rd week after fertilization, when on the periphery with joint cavity sections of $0,2-0,5 \mu \mathrm{m}$ thick, formed of bundles of fine filaments, begin to shape ( $\mathrm{H} \circ \mathbf{r} \mathbf{k} y$ 1985). Thus formed surface can also be found during the 36th to 39th week after fertilization ( $\mathrm{H}$ o $\mathbf{r}-$ $k \dot{y}$ 1983). In this period also the pericellular and intercellular matrix differs in all layers of the cartilage.

Whereas cells of the middle and deep layer reached already during the prenatal periód characteristic signs of differentiated cells, in the superficial layer begin these changes the 3 rd month post partum. On the surface of the cartilage the peripheral layer is formed by a nearly continuous chondral membrane of typical appearance of adult cartilage ( $H \circ \mathbf{r} \mathbf{k}$ ' 1983). In the superficial layer collagen fibrils begin to arrange themselves in layers which cross in a characteristic way, although their size does not reach the size of layers of the adult cartilage ( $\mathrm{H} \circ \mathrm{r} k \dot{y} 1983,1984 \mathrm{~b}$ ). Its final definitive formation, consisting only of quantitative changes occur in the following period. It can be stated that during the $3 \mathrm{rd}$ month of postnatal life the bovine joint cartilage acquires all characteristic features of the adult tissue.

\section{Submikroskopická struktura kloubní chrupavky skotu v prenatálním a časném postnatálním období}

Transmisním a restrovacím elektronovým mikroskopem byla studována kloubní chrupavka 14 jedinců skotu obojího pohlaví v období 36 . týdne po oplození až 3 měs. po narození. V období 36. - 39. týdne po oplození dochází $v$ mezibuněčné hmotě povrchové vrstvy chrupavky $k$ rozlišení na pericelulární a intercelulární matrix. Ve střední vrstvě je vláknitá složka representována převážně kolagenními fibrilami. Tyto fibrily ve vrstvě hluboké jednak opřádají buñky, jednak probíhají $v$ intercelulární matrix neuspořádaně. $\mathrm{V}$ období od narození do 3. měsíce získává kloubní chrupavka všechny podstatné znaky diferencované tkáně jak ve složce buněčné, tak $v$ mezibuněčné hmotě. Zejména vláknitá složka povrchové vrstvy má typické uspořádání v podobě vrstev kolagenních fibril, uložených paralelně s povrchem. Vlákna se $\mathrm{v}$ jednotlivých vrstvách křiži téměr̆ $\mathrm{v}$ pravých úhlech. Ve srovnání $s$ dospělou chrupavkou dochází po 3. měsíci p.p. pouze ke kvantitativním změnám, které spočívají ve zmnožení vláknité složky. V rastrovacím elektronovém mikroskopu se v období 3. měs. po narození objevují skupiny chondrocytů $\mathrm{v}$ mělkých širokých prohlubních; jednotlivé chondrocyty jsou navzájem i od okolí ohraničeny zářezy.

Субмикроскопическая структура суставного хряща крупного рогатого скота в утробный и послеродовый период

Трансмиссионным и расровым электронным микроскопом изучали суставный хрящ крупного рогатого скота в период 36 недель после оплодотворения до 3 месяцев после рождения. Отбор материа- 
ла проводили с головки тазобедренного сустава и обрабатывали обычным способом. В период 36 - 39 недели после оплодотворения в межклеточном поверхностном слое наступает различение перицеллюлярных и интерцеллюлярных ростковых слоев. Волокнистая часть среднего слоя представлена преимущественно коллагеновыми фибриллами. Данные фибриллы в глубоком слое охружают клетки, а также в беспорядке проходят в интерцеллюлярном ростковом слое. В период со дня пождения до 3 месяцев суставный хряm приобретает все сушественные признаки дифференцированной ткани не только в клеточной части, но и в межклеточной массе. В особенности волокнистая составляющая поверхностного слоя отличается характерным слоистым расположением клейдающих фибрилл, находящихся параллельно с поверхностью.Направление волокон в отдельных перехрещивается почти под прямым углом. В последующий период происходят по сравнению с созревшим хрящом лишь количественные изменения, заключающиеся в умножении волокнистой компоненты. В растровом электронном микроскопе с 3 месяца после рождения появляются группы хондроцитов в мелкых и широкых углублениях . Отдельные хондроциты взаимно и от окружения ограничены надрезками .

\section{References}

AGRAWAL, P. - ATRE, P. - KULKARNI, D.D.: The role of cartilage canals in the ossification of the talus. Acta Anat., 119, 1984: 238-241.

ALI, S.Y.: Analysis of matrix vesicles and their role in the calcification of epiphyseal cartilage. Fed. Proc., 35, 1976: 135-142.

ANDERSON, H.C. - SAJDERA, S.W.: Calcification of rachitic cartilage to study matrix vesicle function. Fed. Proc., 35, 1976: 148-152.

BALAZS, E.A.: - BLOOM, G.D. - SWANN, D.A.: Fine structure and glycosaminoglycan content of the surface layer cartilage. Fed. Proc., 25, 1966: 1813-1816.

BEKOFF, M.C. - KLAGSBRUN, M.: Characterization of growth factors in human cartilage. In: Evolution of hormone - receptor systems. Ed.: Bradshaw, R.A., Gill, G.N., Liss, A.R., inc. New York, 1983.

BONUCCI, E.: Fine structure of early cartilage calcification. J. Ultrastruct. Res., 20,1967 : 33-45.

BROWER, T.D. and HSU, W.Y.: Normal articular cartilage. Clin. Orthop., 64 , 1969: 9-17.

BUCKWALTER, J.A. - ROSENBERG, L.: Structural changes during development in bovine fetal epiphyseal cartilage. Collagen. Relat. Res., 3, 1983: 489505.

CAMERON, D.A. and ROBINSON, R.A.: Electron microscopy of epiphyseal and articular cartilage matrix in the femur of the newborn infant. J. Bone Jt Surg., 40 - A, 1958: 163-170.

DRACHMAN, D.B. - SOKOLOFF, L.: The role of movement in embryonic joint development. Develop. Biol., 14, 1966: 401-420.

FELIX, R. - FLEISCH, H.: Role of matrix vesicles in calcification. Fed. Proc., 35, 1976: 169-171.

FREEMAN, M.A.R.: Adult articular cartilage. Ed.: M.A.R. Freeman, Alden Press, Oxford, 1973.

GARDNER, E. - O'RAHILLY, R.: The early development of the knee joint in staged human embryos. J. Anat. (London), 102, 1968: 289-299. 


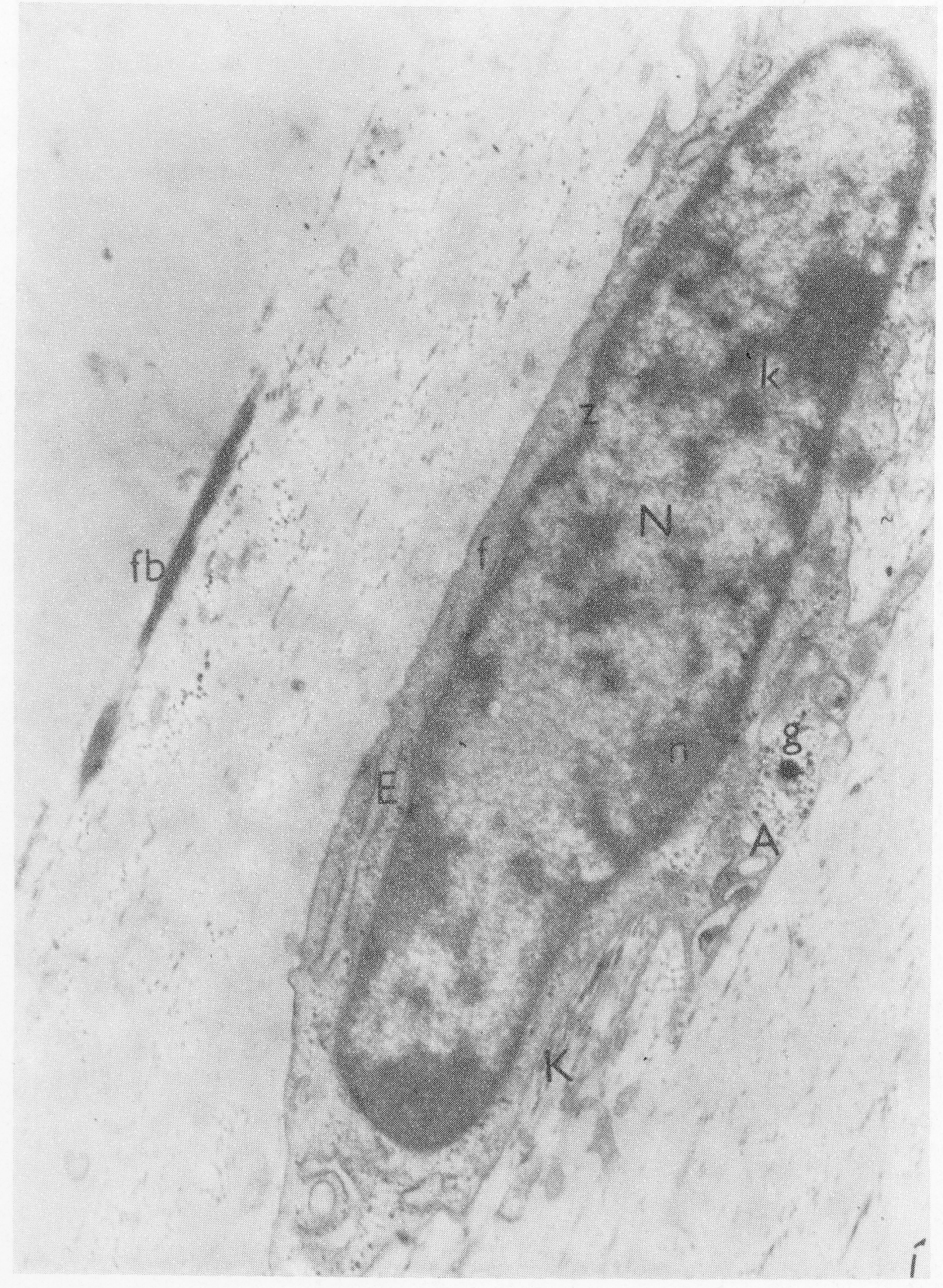




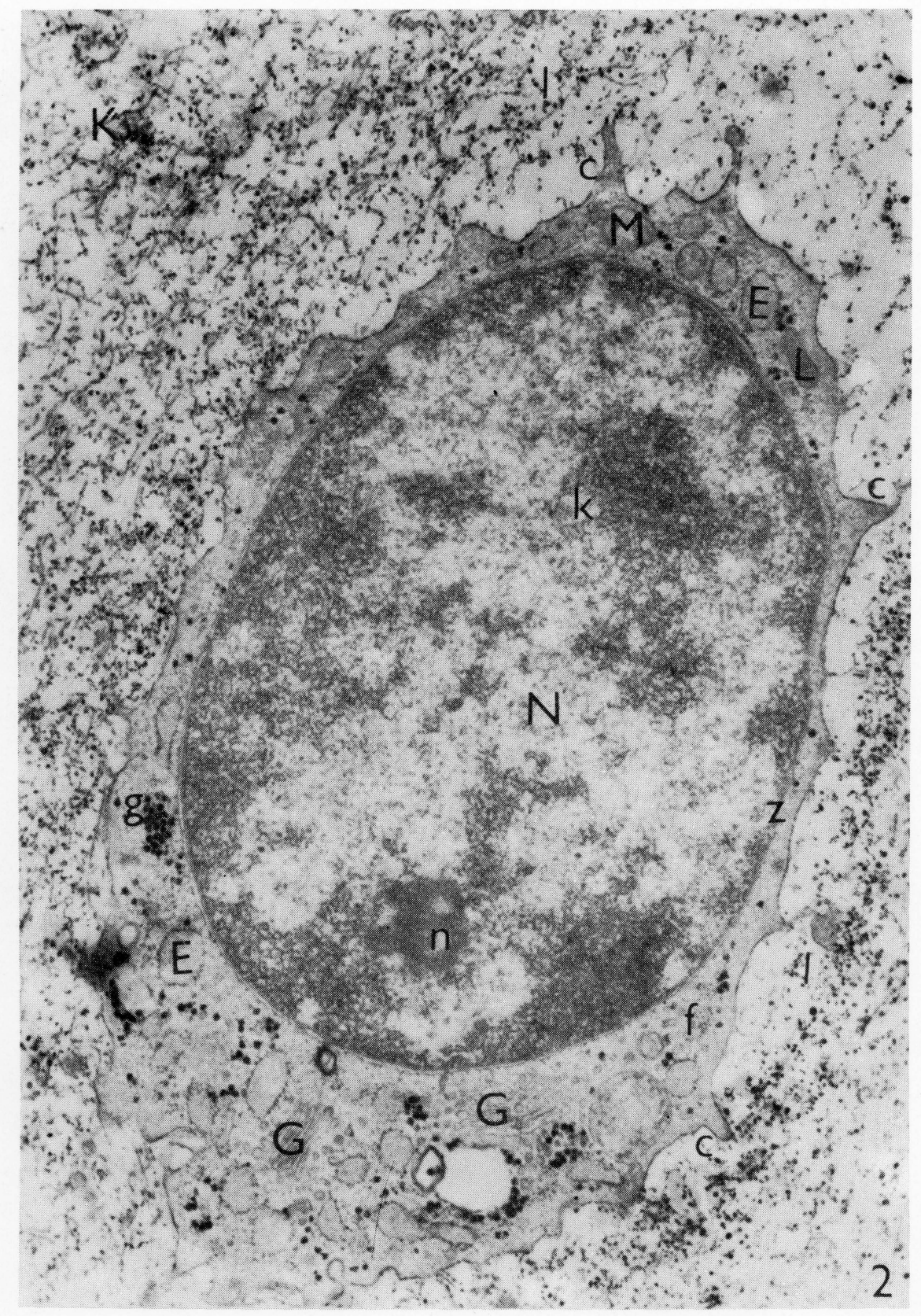




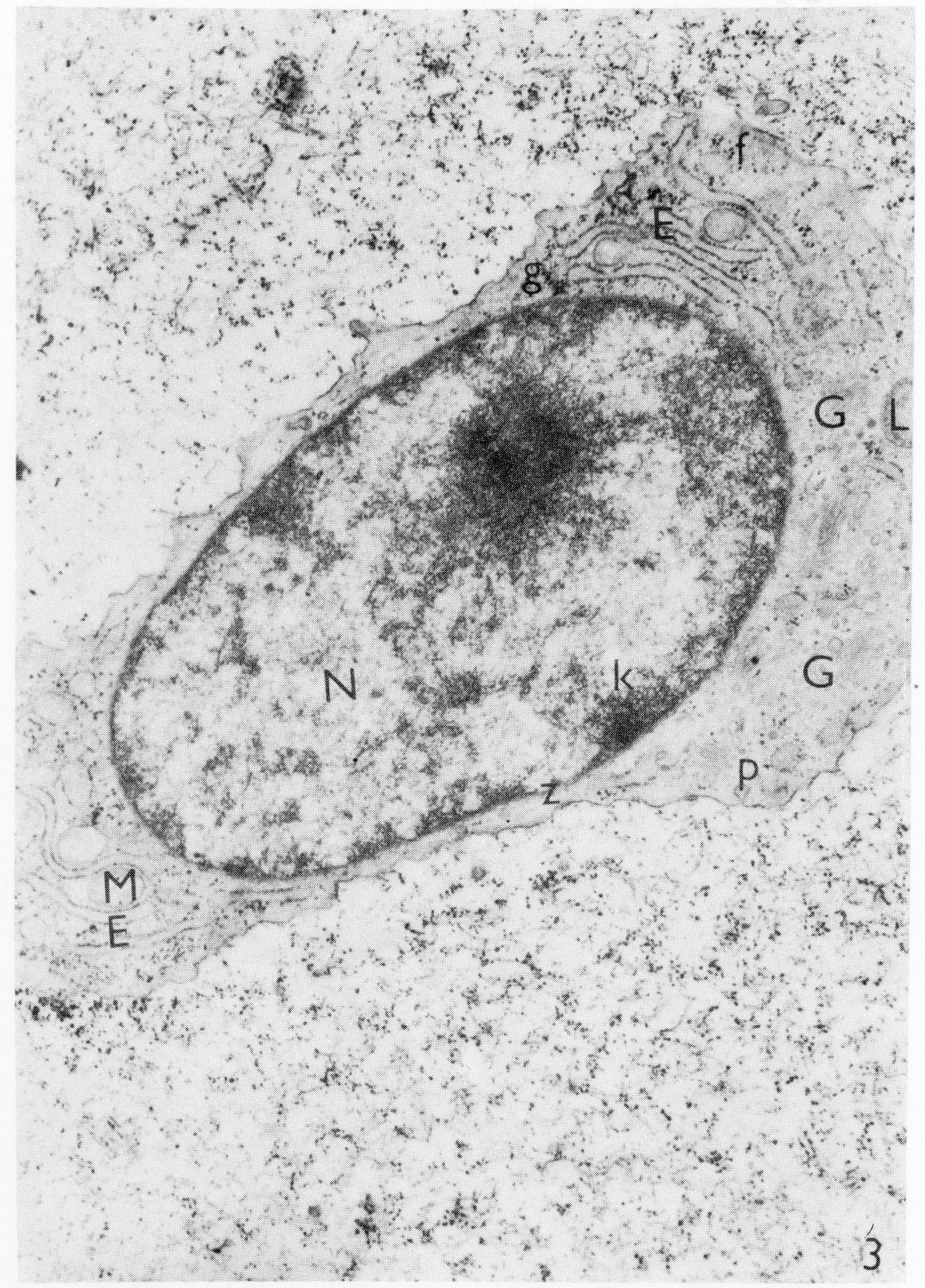




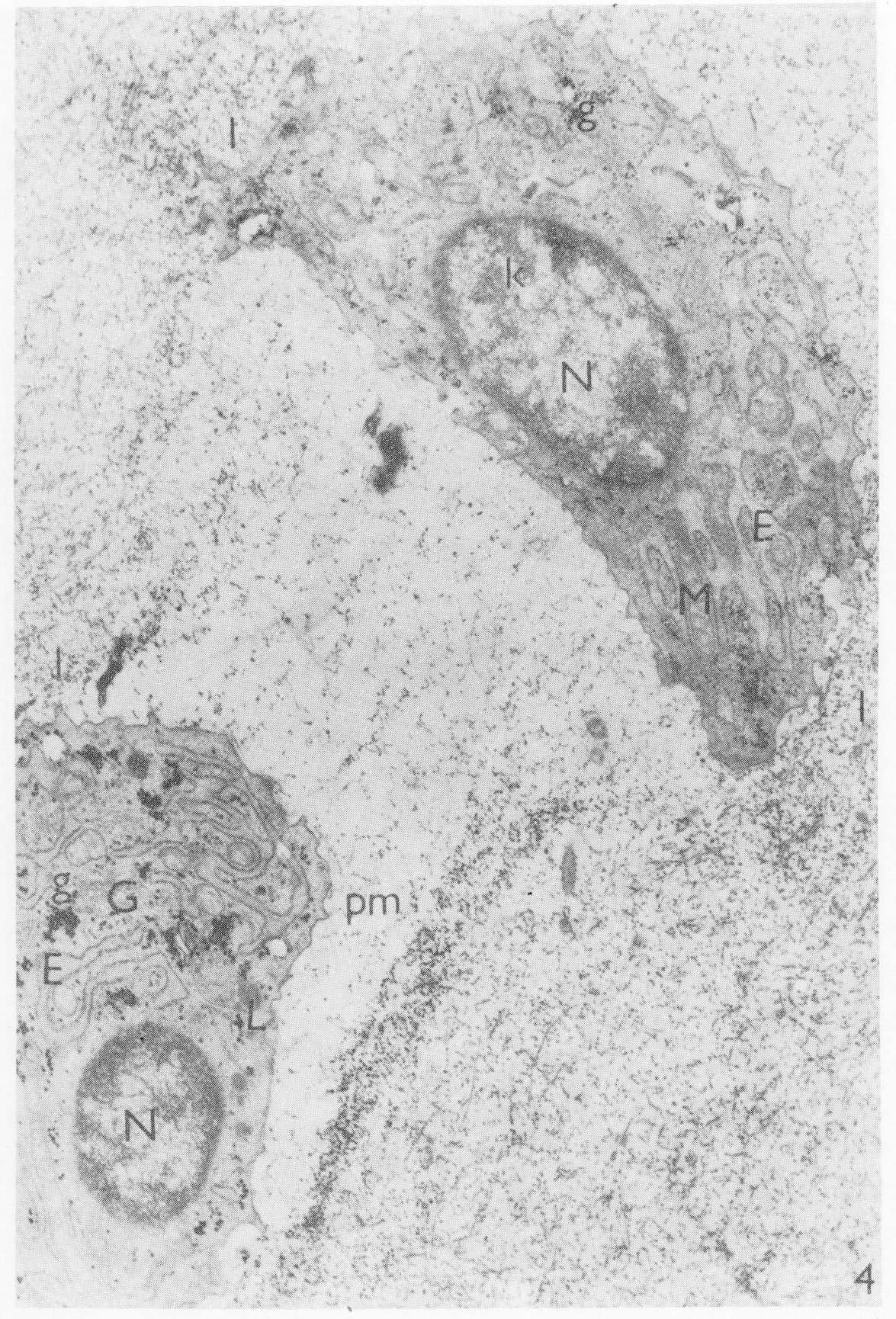




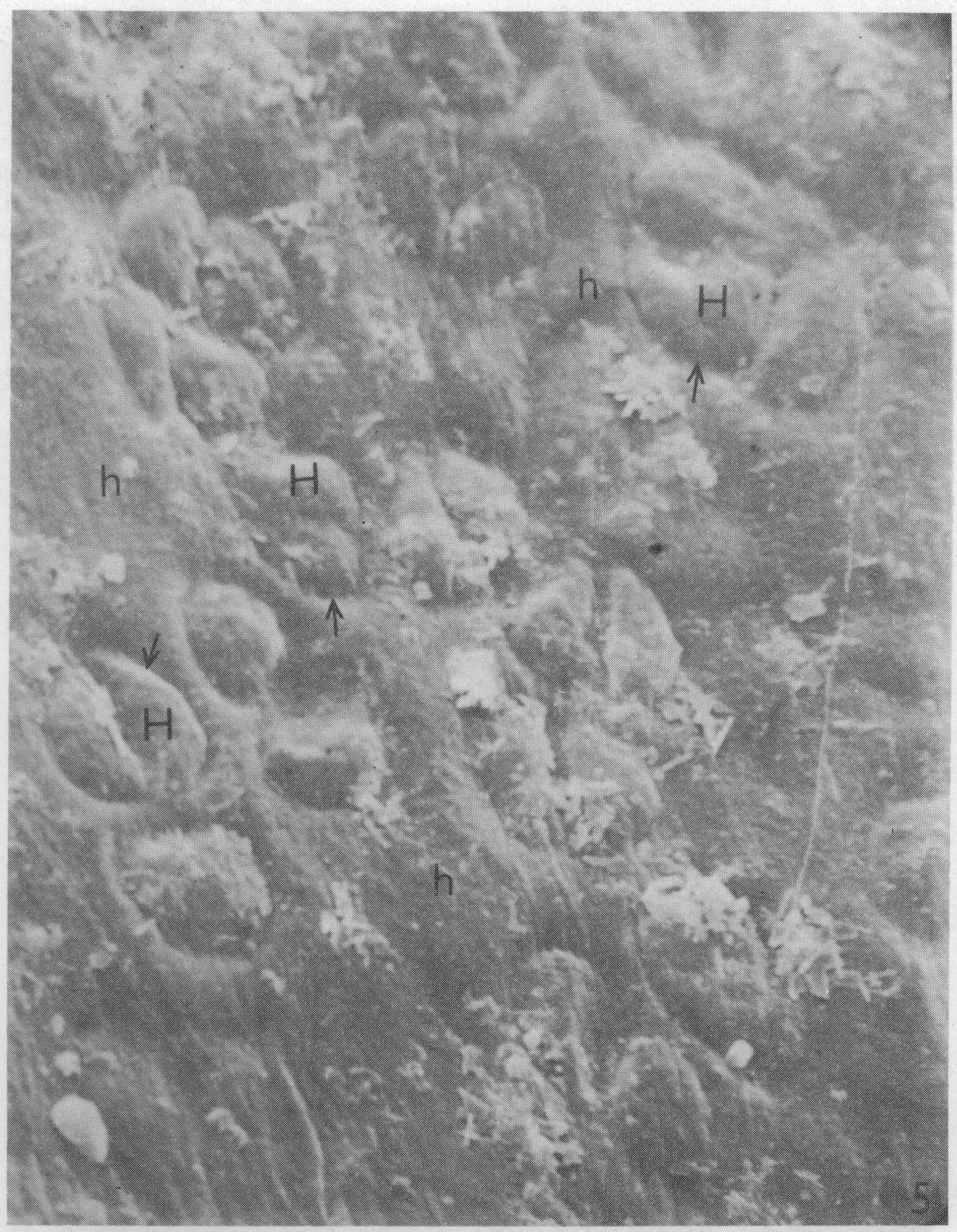




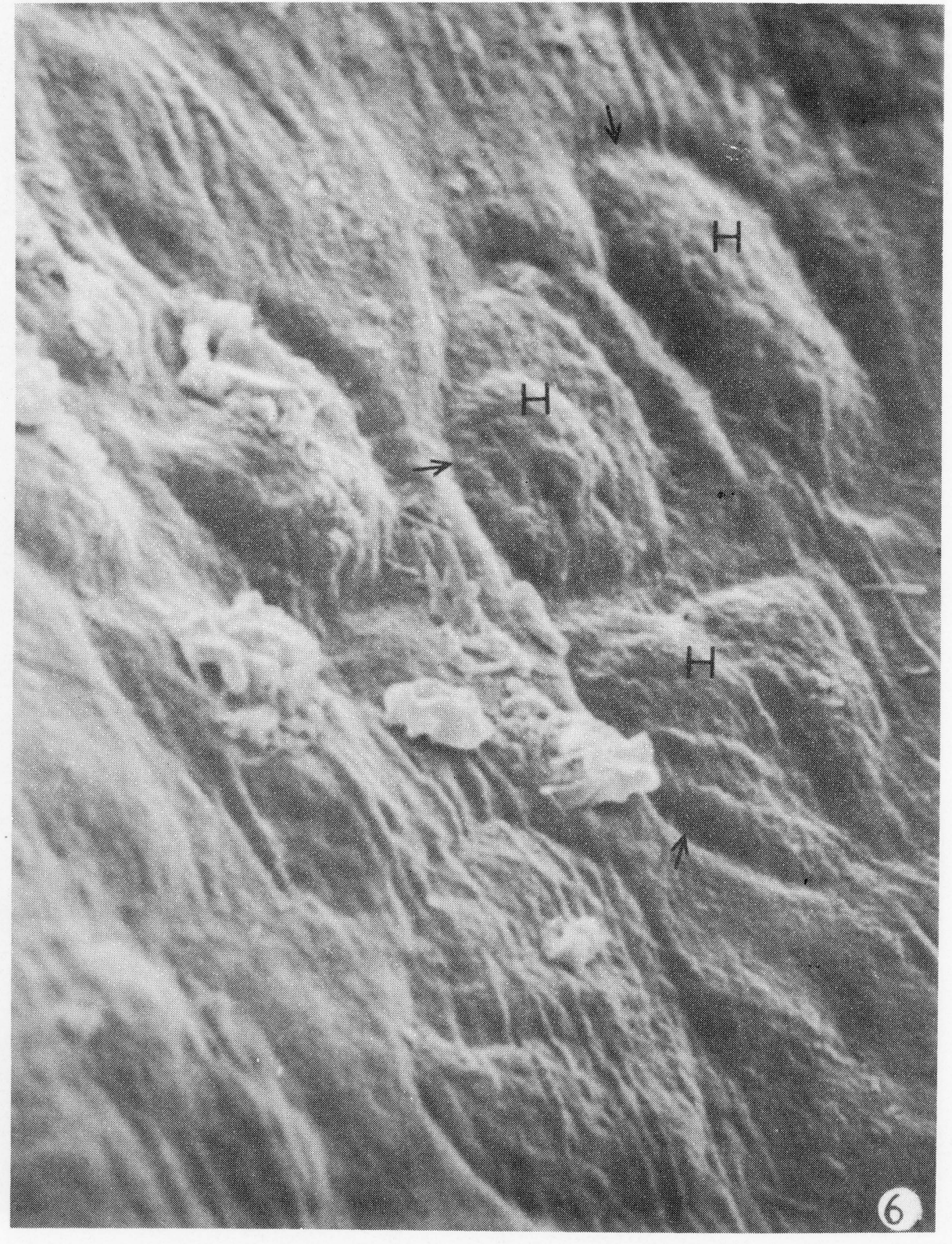




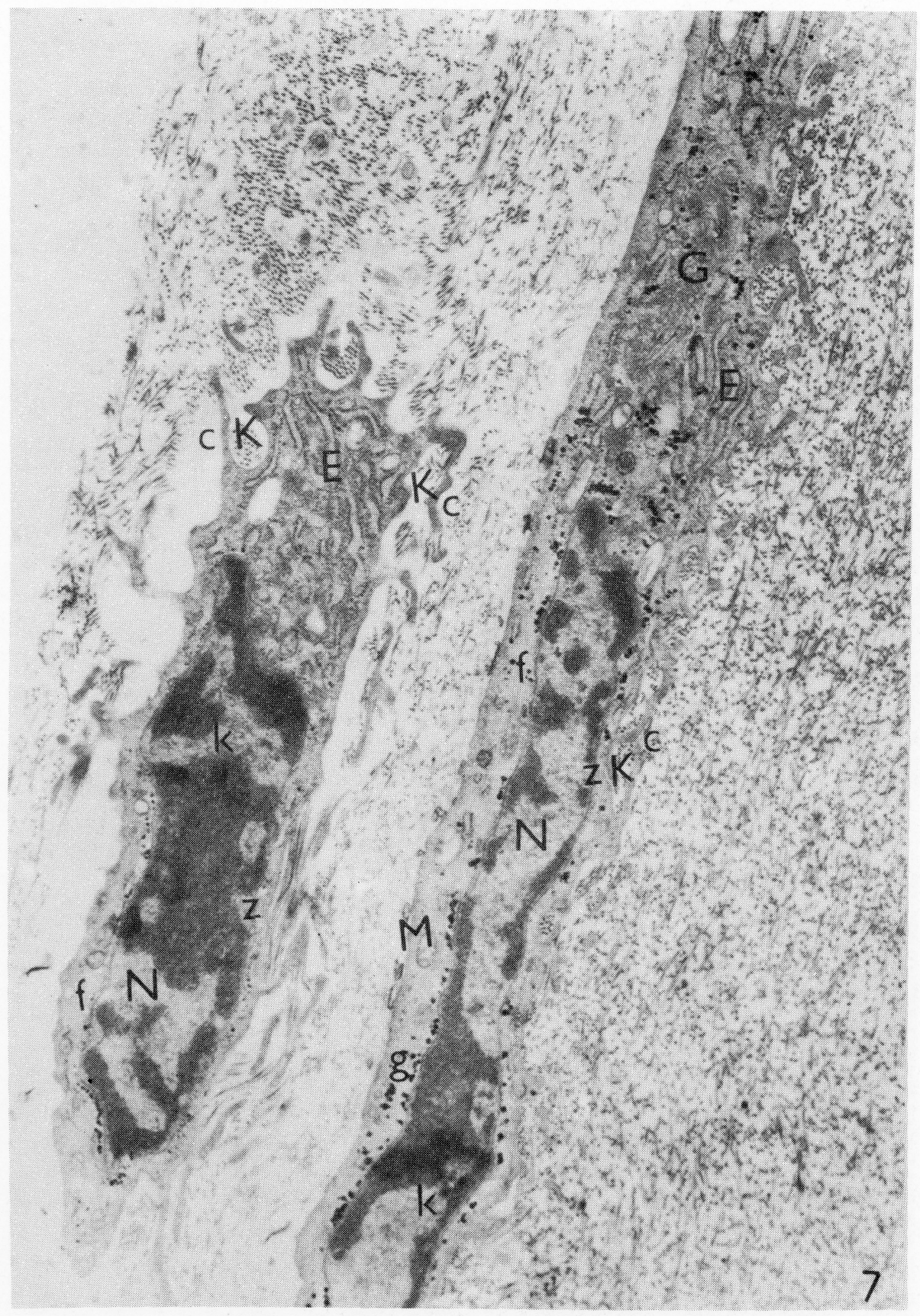




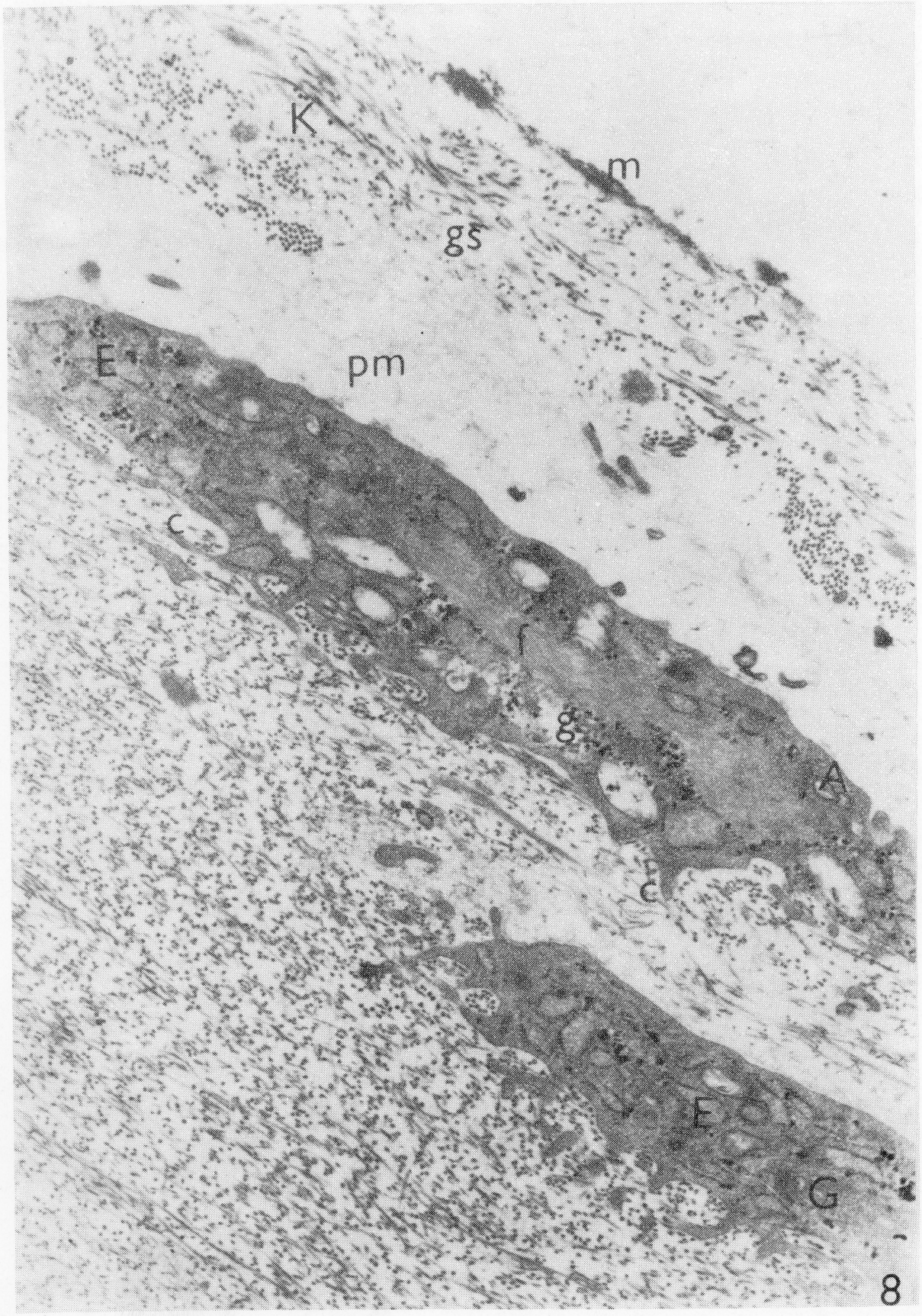




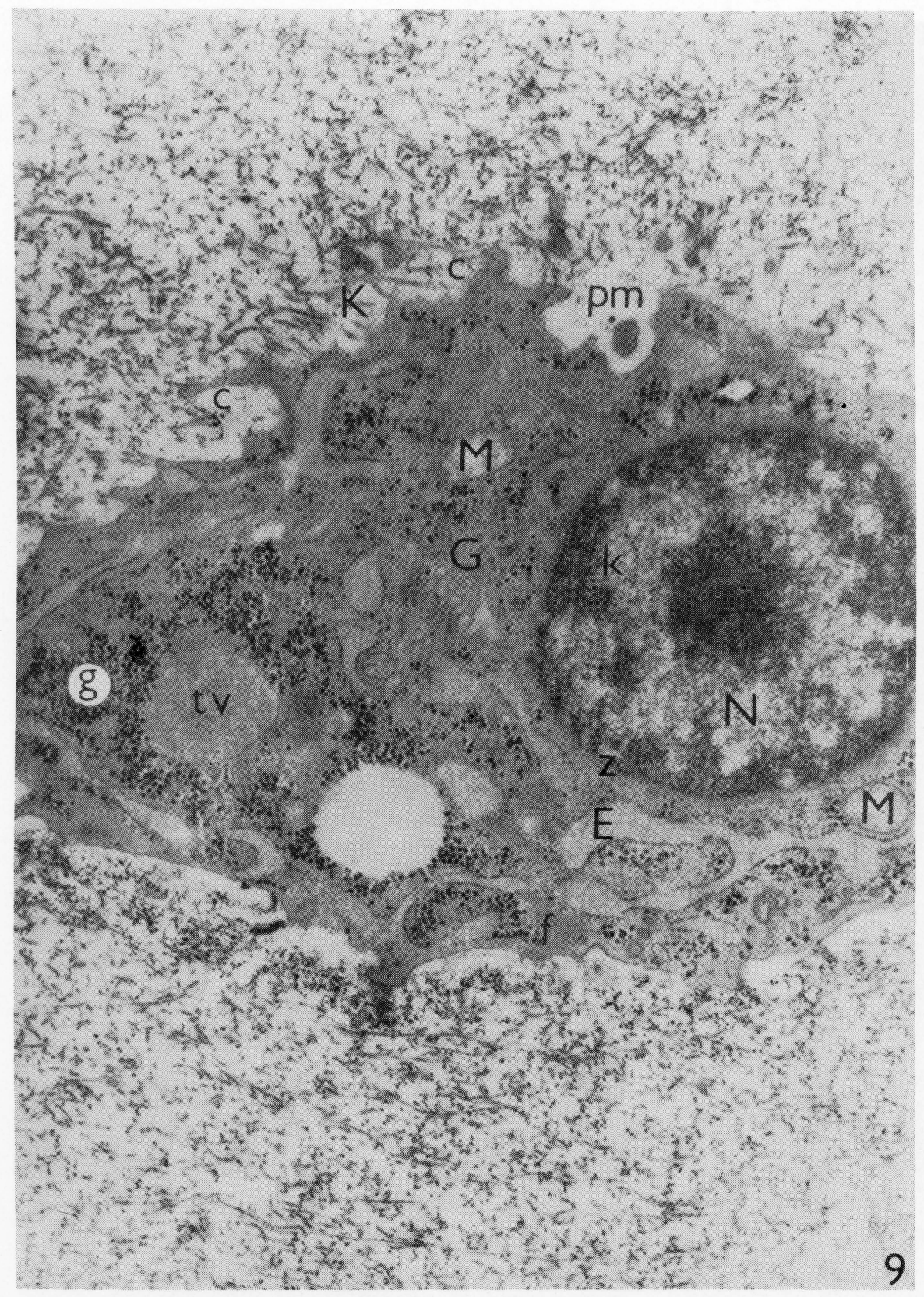




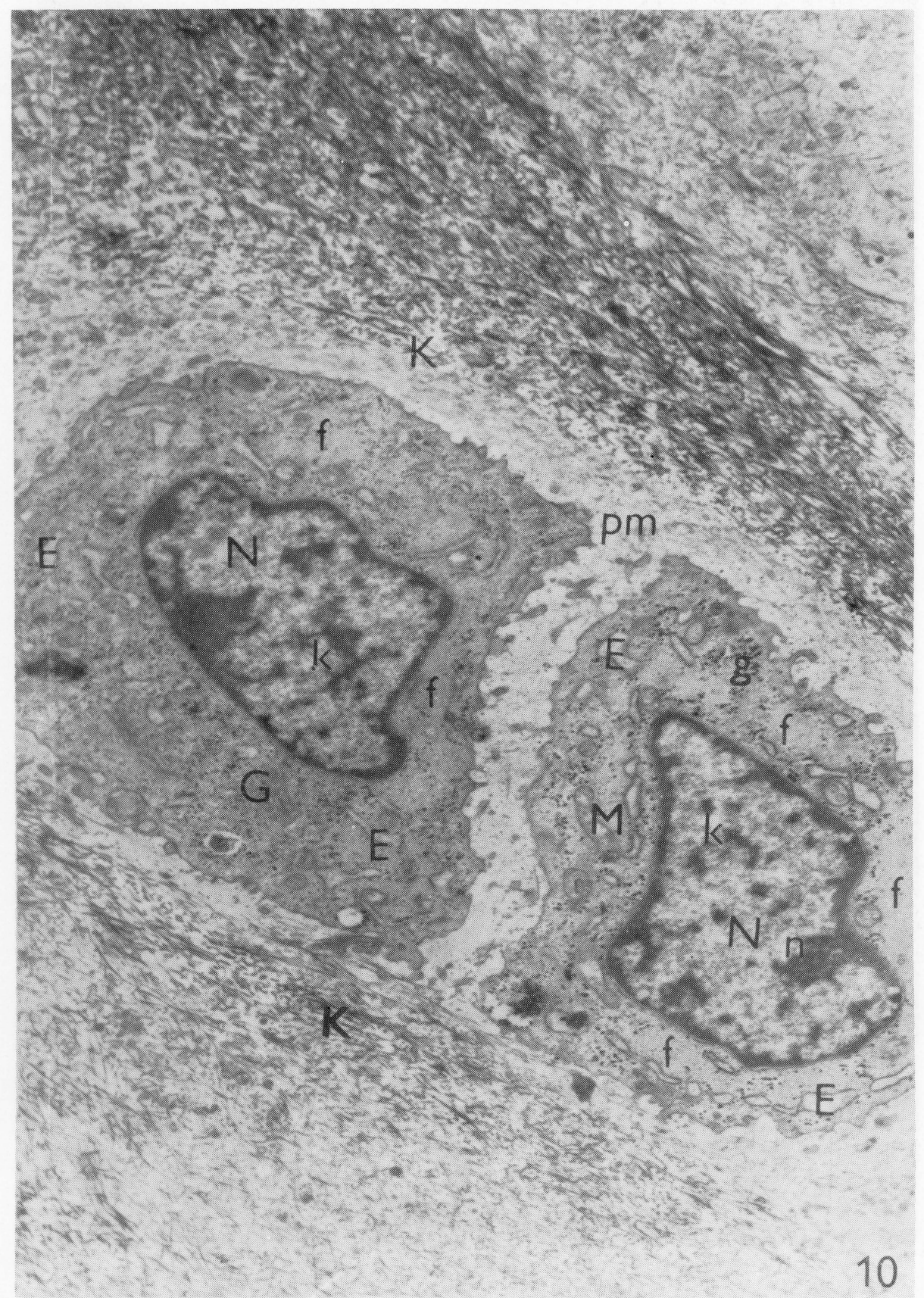




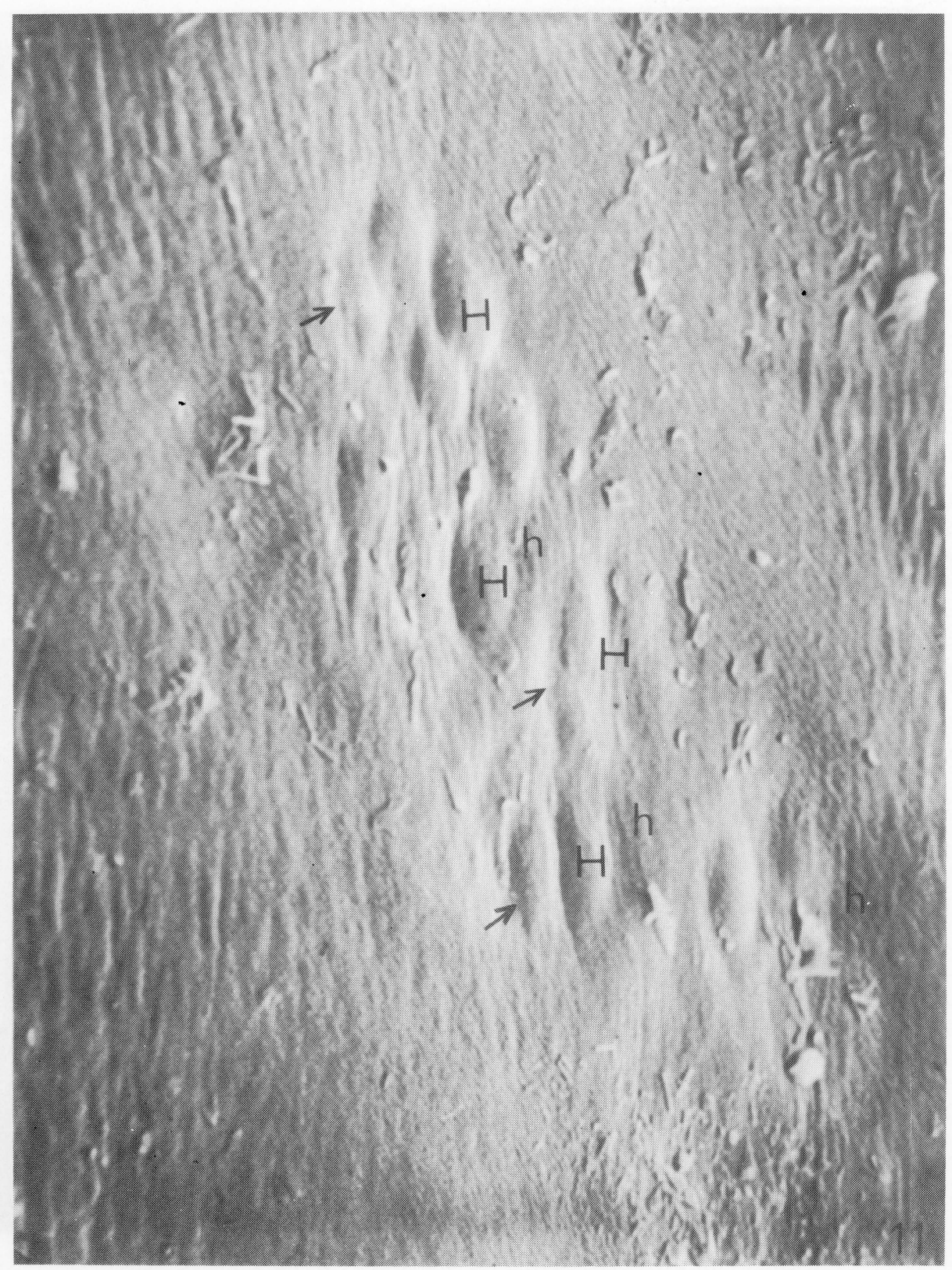




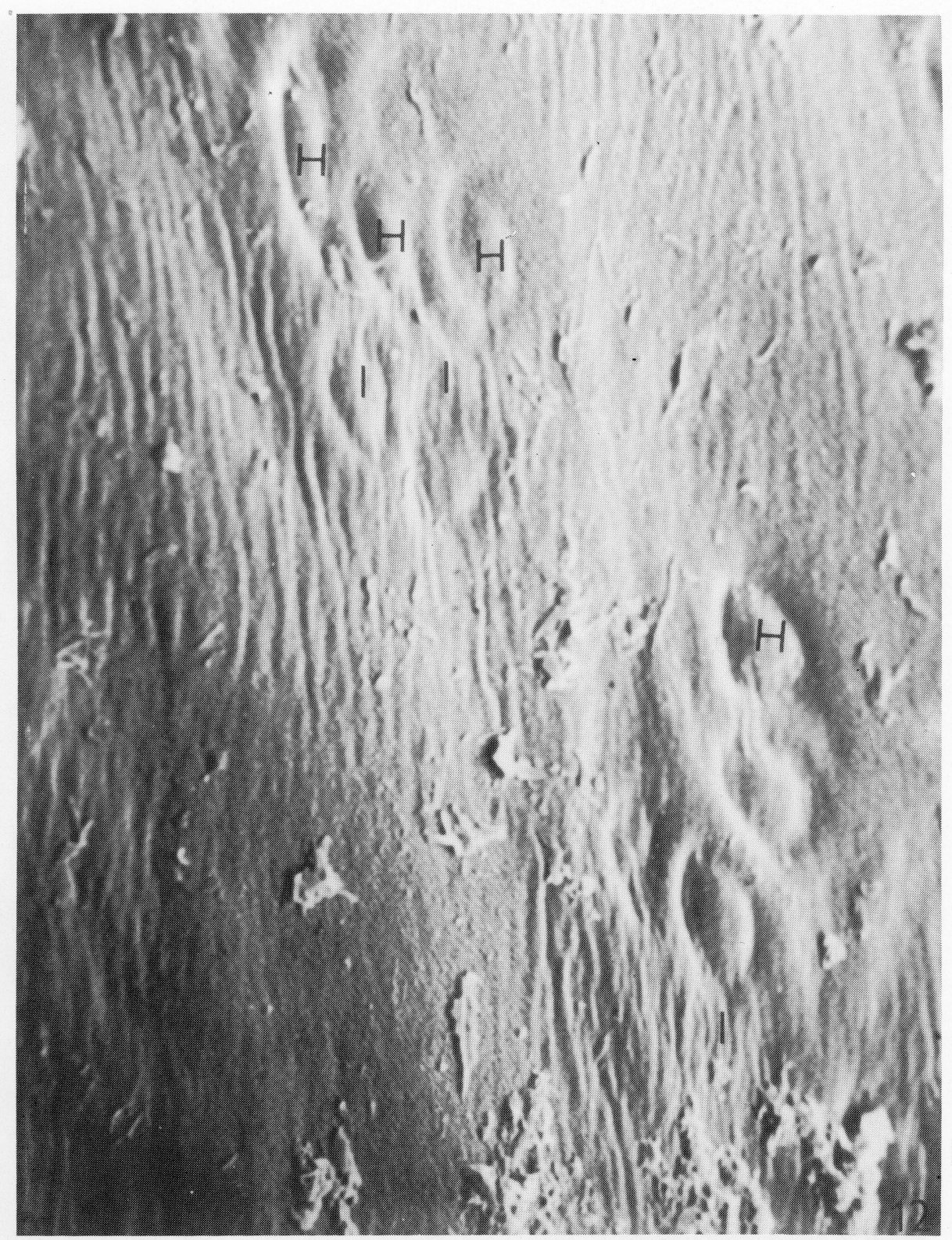


I.

Fig. 1. Part of the superficial layer of bovine joint cartilage 36 th to 39 th week after fertilization. Nucleus of chondroblast (N), nucleolus (n), karyosomes ( $k$ ) and a thin zonula nucleum limitans ( $z$ ). Granular endoplasmic reticulum (E), agranular endoplasmic reticulum (A), granules of glycogen $(\mathrm{g})$, intracytoplasmic filaments in fine bundles (f). On the surface of cartilage bundles of fine fibrillar material are found $(\mathrm{fb})$ and in the ground amorphous substance are besides aperiodic also collagen fibrils (K) projecting to the cell membrane. Magnification, x 21.400 .

Fig. 2. Chondroblast of the middle layer of bovine joint cartilage 36 th to 39 th week after ferilization. Nucleus (N), karyosomes (k), nucleolus of reticular type $(n)$, zonula nucleum limitans ( $z$ ). Dilated cisternae of granular endoplasmic reticulum (E) with synthesized material, the distinct Golgi complex (G), mitochondria (M), lysosomes (L), small clusters of glycogen $(\mathrm{g})$, discrete bundles of filaments (f). Short projections of the cytoplasm (c) end close to intercellular matrix (I), where also collagen fibrils may be found (K). Magnification, x 20.000 .

Fig. 3. Chondroblast of the middle layer of bovine joint cartilage 36 th to 39 th week after fertilization. Nucleus (N) with karyosomes (k) and a thin zonula nucleum limitans $(z)$. Cisternae of granular endoplasmic reticulum (E), a distinct Golgi complex (G), mitochondria (M), lysosomes (L), glycogen ( $g$ ), intracytoplasmic filaments ( $f$ ), pinocytotic vesicles (p). The cell membrane and the intercellular substance show the same arrangement as in previous figure. Magnification, x 16.000 .

Fig. 4. Pairs of chondroblasts of the deep layer of bovine joint cartilage 36 th to 39 th week after fertilization. Nucleus (N) with karyosomes (k). Dilated cisternae of the granular endoplasmic reticulum (E), mitochondria (M), an inexpressive Golgi complex (G), lysosomes (L), numerous small clusters of glycogen $(\mathrm{g})$. The intercellular substance is differentiated to pericellular (pm) and intercellular matrix which is in contact with a part of the cell surface (I). Magnification, $x$ 24.000 .

Fig. 5. Appearance of bovine joint cartilage 36th to 39 th week after fertilization. Groups of rounded elevations are formed $(H)$, only slightly elevating over the surface. Surrounding incision $(\rightarrow)$ is deeper than in the previous stage and areas between the groups are widening (h). Scanning electron microscope. Magnification, x 2.200.

Fig. 6. Detail of the surface of bovine joint cartilage 36th to 39 th week after fertilization. Groups of elevations (N) rimmed by an incision $(\rightarrow)$. Light waved surface on spaces between groups and on the elevations. Scanning electron microscope. Magnification, x 4.200. 
Fig. 7. The superficial layer of bovine joint cartilage 3 months after birth. Nuclei of chondrocytes (N) with large karyosomes (k), zonula nucleum limitans $(z)$. Numerous cisternae of granular endoplasmic reticulum (E), Golgi complex (G), mitochondria (M) with a clear matrix, here and there granules of glycogen $(g)$, bundles of intracytoplasmic filaments (f). Collagen fibrils (K) are deposited near the cell membrane between projections of the cytoplasm (c). Magnification, $x$ 6.000 .

Fig. 8. The superficial layer of bovine joint cartilage 3 months after birth. In the cytoplasm of chondrocytes dilated cisternae of granular endoplasmic reticulum (E), agranular endoplasmic reticulum (A), Golgi complex $(G)$, glycogen ( $g$ ), bundles of intracytoplasmic filaments ( $f$ ) occupy a large area. On the surface of cartilage the chondral membrane (m) and in the ground amorphous substance (gs) collagen fibrils cross under right angles. Pericellular matrix (pm) is formed in direction to the surface. Cytoplasm on the upturned side runs into projections (c) reaching intercellular matrix. Magnification, $x 6.000$.

Fig. 9. Part of the middle layer of bovine joint cartilage 3 months after birth. Nucleus of chondrocytes (N), karyosomes (k), zonula nucleum limitans $(z)$. Wide dilated cisternae of granular endoplasmic reticulum (E), Golgi complex $(G)$ is deposited into several fields, transport vacuoles (tv), mitochondria (M). Glycogen (g) forms large clusters, bundles of intracytoplasmic filaments (f). Pericellular matrix (pm) is narrow, intercellular collagen fibrils in matrix (K) in contact with projections of the cytoplasm (c). Magnification, $x$ 16.000 .

Fig. 10. The deep layer of bovine joint cartilage 3 months after birth. Pairs of chondrocytes in a common lacuna (pm). Nuclei (N), karyosomes $(k)$, nucleolus ( $n$ ). Cisternae of granular endoplasmic reticulum (E), mitochondria (M), Golgi complex (G), glycogen (g), thick bundles of intracytoplasmic filaments (f). Collagen fibrils (K) are concentrically arranged round pericellular matrix. Magnification, x 6.000 .

Fig. 11. Appearance of bovine joint cartilage 3 months after birth. The surface of cartilage is sinking in shape of wide shallow grooves (h) and pn their bottom groups of elevations (H) are deposited, rimmed by incisions $(\rightarrow)$ separating them from the surrounding. Light waved surface on areas of the surrounding groups and on the surface of elevations. Scanning electron microscope. Magnification, $\mathrm{x} 2.100$.

Fig. 12. Appearance of bovine joint cartilage 3 months after birth. Groups of chondrocytes $(\mathrm{H})$ in the shallow depressions on bottom of the grooves. Waved surface (1) also on the bottom of grooves on the surface of chondrocytes. Scanning electron microscope. Magnification, x 2.100 . 
GARDNER, E. - GRAY, D.J.: The prenatal development of the human femur. Am. J. Anat., 129, 1970: 121-140.

GHADIALLY, F.N.: Fine structure of synovial joints. Butterworths, London, 1983.

GLENISTER, T.W. An embryological, view of cartilage. J. Anat. (London), 122, 1976: 323-330.

GODMAN, G.C. - LANE, N. - PORTER, K.R.: Chondrogenesis. Studies with the electron microscope. J. Biophys. Biochem. Cytol., 8 , 1960: 719-732.

GOULD, R.P. - SELWOOD, L. - DAY, A.: The mechanism of cellular orientation during early cartilage formation in the chick limb and regenerating amphibian limb. Exp. Cell Res., 83 , 1974: 287-296.

GRAY, D.J. - GARDNER, E.: Prenatal development of the human humerus. Am. J. Anat., $124,1969:$ 431-446.

GREEN, W.T.Jr.: Behavior of articular chondrocytes in cell culture. Clin. Orthop., 75 , 1971: 248-260.

HAINES, R.W.: Cartilage canals. J. Anat. (London), 68, 1933: 45-64.

HANAOKA, H.: The fate of hypertrophic chondrocytes of the epiphyseal plate. An electron microscopic study. J. Bone Jt Surg., 58, 1976: 226-229.

HORKY, D.: Ontogenic development of the ultrastructure of bovine joint cartilage. Acta vet. Brno, 52, 1983: 103-130.

HORKY, D.: Ultrastructure of the bovine synovial membrane in ont ogenesis. Acta vet. Brno, 53, 1984 a: 107-117.

HORKY, D.: Ultrastruktuta kloubní chrupavky a synoviální membrány skotu v ontogenezi. Acta Facult. Med. Univ. Brunensis, 57, 1984 b: 319.

HORKY, D.: U1trastructure of bovine articular cartilage between weeks 8 and 23 of prenatal development. Acta vet. Brno, 55, 1986: 227-246.

HURREL, D.J.: The vascularization of cartilage. J. Anat. (London), 69 , 1934: 47-61.

IMURA, S.: Intracytoplasmic collagen fibers observed in cartilage of the pathological conditions. J. Jpn. Orthop. Ass., 58, 1984: 125-137.

KLAMFELDT, A.: Synthesis of articular cartilage proteoglycans by isolated bovine chondrocytes - effect of autogenous conditioned synovial medium in vitro. Agents and Actions, 14, 1984: 58-63.

LAMAR, C.H. - Van SICKLE, D.C. - BRANDMAN, P. - HINSMAN, E.J.: Ultrastructure of timed isolates of in vitro canine articular chondrocytes. Am. J. Vet. Res., 41, 1980: 241-243.

LEVENE, C.: The pattern of cartilage canals. J. Anat. (London), 98, 1964: 515-538.

LEVITT, D. - DORFMAN, A.: Concepts and mechanism of cartilage differentiation. In: Current Topics in Development Biology. Ed.: Moscona and Monroy, Academic Press, New York, London, 1974.

LUFTI, A.M.: The mode of growth, fate and function of cartilage canals. J. Anat. (London), $106,1970: 135-145$.

MAROUDAS, A. - BULLOUGH, P.: Permeability of articular cartilage. Nature, $219,1968: 1260-1261$.

MAROUDAS, A.: Physico-chemical properties of articular cartilage. In: Adult articular cartilage. Ed: M.A.R. Freeman, Alden Press, Oxford, 1973.

NIJWEIDE, P.J. - BURGER, E.H. - HEKKELMAN, J.W. - HARRMANNERLEE, M.P.M. GAILLARD, P.J.: Regulatory mechanisms in the development of bone and cartilage - the use of tissue culture techniques in the study of the development of embryonic bone and cartilage - a perspective. Factors Mech. Bone Growth, 1982.

ORYSCHAK, A.F. - GHADIALLY, F.N. - BHATNAGAR, R.: Nuclear fibrous lamina in the chondrocytes of articular cartilage. J. Anat. (London), 118 . 1974: 511-515. 
PUIG - ROSADO, A.: Articular chondrogenesis. An experimental study in immature rabbits. J. Bone Jt Surg., 63 B, 1981: 619-622.

SANZONE, C.F. - REITH, E.J.: The development of the elastic cartilage of the mouse pinna. Am. J. Anat., 146, 1976: 31-71.

SATO, K. - URIST, M.R.: Bone morphogenetic protein - induced cartilage development in tissue culture. Clin. Orthop., 183, 1984: 180-188.

SCHECK, M. - PARKER, J. - SAKOVICH, L.: The fine structure of proliferating cartilage cells: structural changes in an experimental model. Am. J. Anat., 119 , 1975: 435-452.

SCHERFT, J.P.: The lamina limitans of the organic matrix of calcified cartilage and bone. J. Ultrastruct. Res., 38 , 1972: 318-331.

SILBERMANN, M. - FROMMER, J.: Ultrastructure of developing cartilage in the mandibular condyle of the mouse. Acta Anat. (Base1), 90, 1974: 330-346.

SOLURSH, M. - HENSEN, K.L. - SINGLEY, C.T. - LINSENMAYER, T.F. - REITER, R.S.: Two distinct regulatory steps in cartilage differentiation. Develop. Biol., 94 , 1982: 311-325.

STINGL, J.: Ultrastruktura synoviálních struktur v časné ontogenezi člověka. Sborník prací III. kongresu o sportovní traumatologii, Třeboñ, 1982.

STOCKWELL, R.A.: The ultrastructure of cartilage canals and the surrounding cartilage in the sheep fetus. J. Anat. (London), 109,1971 a: 397-410.

STOCKWELL, R.A.: The interrelationship of cell density and cartilage thickness in mammalian articular cartilage. J. Anat. (London), 109 , 1971 b: 411-421.

STOCKWELL, R.A. - MEACHIM, G.: The chondrocytes. In: Adult articular cartilage. 2nd edition. Ed. M.A.R. Freeman, London, Pitman Medical 1979.

THYBERG, J. - LOHMANDER, S. - FRIBERG, U.: Electron microscopic demonstration of proteoglycans in guinea pig epiphyseal cartilage. J. Ultrastruct. Res., 45 , 1973: 407-427.

VIDINOV, N. - VASILEV, V.: Cilia in rat articular chondrocytes. Anat. Anz. Jena, $158,1985:$ 51-55.

WILSMAN, N.J. - FLETCHER, T.F.: Cilia on neonatal articular chondrocytes incidence and morphology. Anat. Rec., 190, 1978: 871-889.

WOLF, J.: Chondrosynovial membrane serving as joint cavity lining with a sliding and barrier function. Folia Morphol. (Prague), $17,1969:$ 291-308.

WOLF, J.: Function of chondral membrane on surface of articular cartilage from point of view of its mechanical resistence. Folia Morphol. (Prague), 23 , 19.75: 77-87. 